\title{
The mediating role of self-brand connection and brand identity in the relationship between brand credibility and brand loyalty
}

\author{
Nguyen Ngoc Dan Thanh ${ }^{1 *}$, Nguyen Duc Thanh ${ }^{1}$, Le Thi Thanh Thuy ${ }^{1}$, Do Minh Thuy ${ }^{1}$, \\ Nguyen Thi Thanh Thao ${ }^{1}$, Tong Nguyen Phuong Thanh ${ }^{1}$ \\ ${ }^{1}$ Faculty of Business Administration, Ho Chi Minh City Open University, Vietnam \\ *Corresponding author: thanh.nnd@ou.edu.vn
}

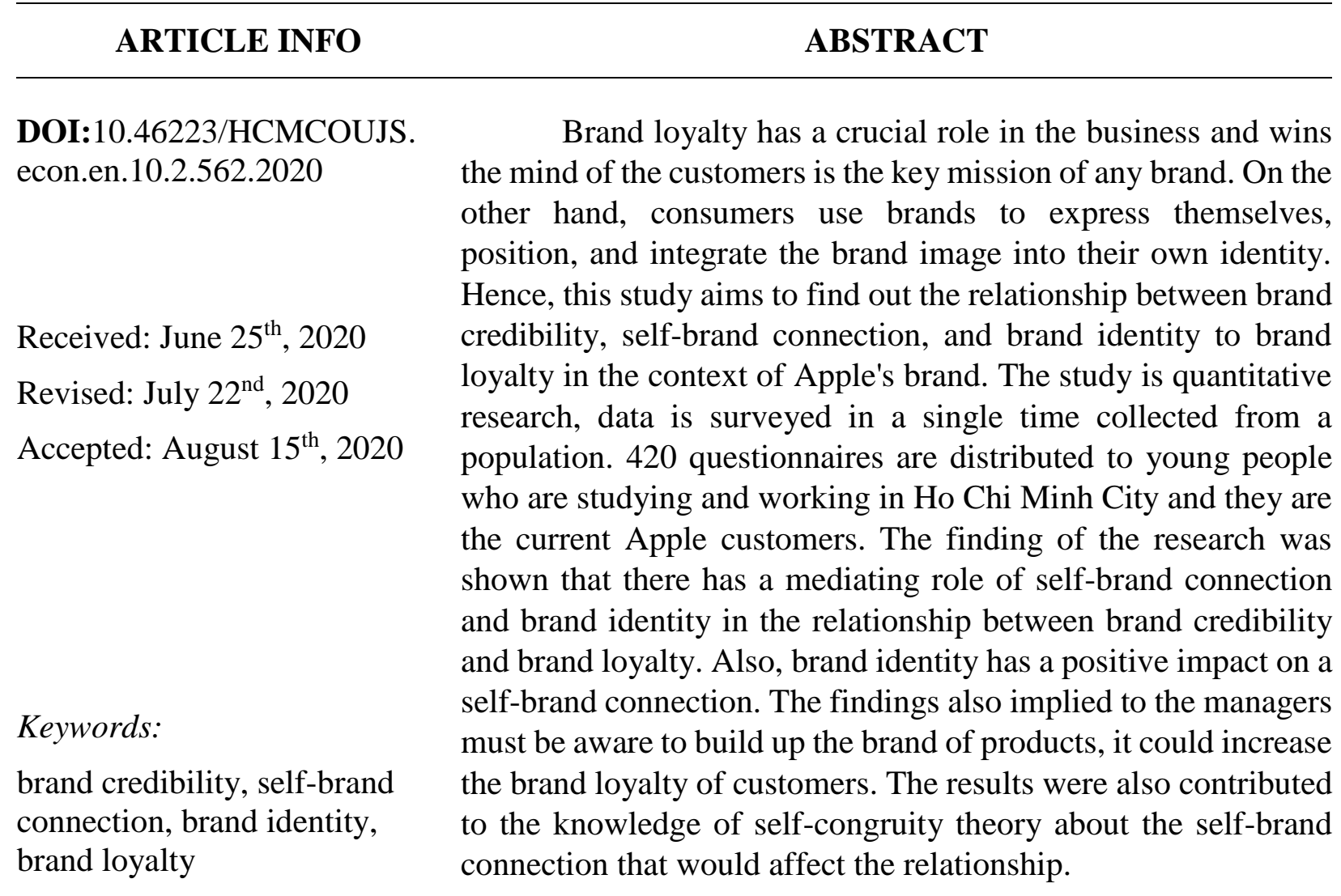

\section{Introduction}

In the current technology market, many new brands have appeared, leading to fierce competition in market share. Brand loyalty is studied by many researchers. On the other hand, if the customers rely on brand when consumers receive negative public opinion, they tend to defend and preserve their previously self-determined beliefs by treating negative information in a biased and defensive way (Einwiller, Fedorikhin, Johnson, \& Kamins, 2006). The ability to recover positive information previously available may occur. Because brand identity enhances the willingness to engage in behaviors beyond the role of consumers, such as politeness, altruism, ... (Bergami \& Bagozzi, 2000; Sen, Du, \& Bhattacharya, 2009). According to that, the consumer tends to be more clement when the incident occurred (Bhattacharya \& Sen, 2003). Besides, the number of customers waiting as the company prepares for new product launches, they are ready to buy that product willing to pay with the premium price. Because, at that time, the decision to buy the product is from the emotional effect and the result of loyalty to that brand. To develop brand loyalty, if the consumer is exposed, used, familiar with the brand, brand loyalty will gradually be established (Stokburger-Sauer, Ratneshwar, \& Sen, 2012). In 2014, Banister and 
Cocker said that consumers use the brand to represent their position and image. It is shown by the customers' lifestyle, style, personality, and that brand will contribute to creating this value. So it can be seen that consumers connected to the brand will lead to their loyalty to that brand.

In addition, Brand identity plays an important role in developing brand loyalty. StokburgerSauer et al. (2012) found that when consumers' brand identity is strong, loyalty to that brand is higher and it keeps the consumers stay with the brand.

Besides, brand credibility also affects on brand loyalty. A study by Gilovich, Kumar, and Jampol (2015) found that the stronger the brand credibility is, the more It is used by consumers to express themselves. When consumers believe that a brand is credible, they will have repeat purchase behavior the brand's product, forming a self-connecting brand, thereby developing behavioral loyalty to the brand.

In this research topic, the brand chosen to conduct research is Apple - one of the top brands on the market now. As of 2019, Apple with brand equity of 234.2241 billion USD, for 7 consecutive years was the leading brand globally on the list of Top 100 brands of the world (according to Interbrand). According to Forbes, the reason for that result comes from the sustainability of building brand loyalty of customers. First, Apple is building strong brand credibility. By fulfilling our commitment to the public to create the best quality software and product systems. Following that, Steve Jobs' dedication to Apple gave customers somewhat confidence in product quality. Apple is recognized as the way customers identify a talented CEO, a Steve Jobs that creates a balance with the rest of the smartphone market. Finally, by creating an emotional connection with consumers, Apple has done what seemed impossible - the loyalty of a huge customer base around the world. The facts about Apple mentioned above partly outline the model outline of the topic: The mediating role of self-brand connection and brand identity in the relationship between brand credibility and brand loyalty. So, this research is looking forward to helping the business with a more important view of building customer loyalty.

Moreover, this research will be useful material for executives while making brand decisions. Therefore, this study has the following main objectives: 1) investigate the relationship between brand credibility and brand loyalty, 2) explore the mediation role of self-brand connection and brand identity in the relationship between brand credibility and brand loyalty.

\section{Literature review}

\subsection{Theory of self-concept and self-congruity}

Self-congruity is self-concept and has been extensively studied in psychology and social psychology. According to Grubb and Grathwohl (1967), when they refered to themselves as when they perceive an attitude, a feeling, perception, and judgment as an object. So the concept of selfconcept (or self-image) is considered as a combination of reason and personal feelings related to the self (Rosenberg, 1989). In this context, the concept of self is a multidimensional concept (Malhotra, 1988; Sirgy, 1980), And each of these dimensions is referred to as each self-concept, the concept of self-ideation. want to see themselves or what they want to be], the concept of social self [their image in the eyes of others] and the ideal social concept [consumers want to be asserted in the society they give birth to live] (Sirgy, 1982, 2018; Todd, 2001). Also, Levy (1959) emphasized that in current consumer behavior, customers are more likely to purchase products and services because of intangible rather than tangible factors. Grubb and Grathwohl (1967) also found that consumers tend to associate their image with the product they buy with brand pride. This idea has been supported by many researchers (Aaker, 1999; Malhotra, 1988; Sirgy, 1980, 1982; Sirgy $\&$ Samli, 1985) that have contributed significantly to the development of SC theory. 
Therefore, the theoretical basis of self-congruity has been explained with an assertion that consumers consider the product/brand they buy as self-expression and they tend to like products/brands with similar images. with their concepts (Graeff, 1996; Sirgy \& Samli, 1985). Therefore, consumers may be inclined to buy a product that reflects themselves and refuse to buy another product because it does not fit their image (Sirgy \& Samli, 1985). Since then, they have more loyal buying behavior with the brand, which is closely linked to that brand.

\subsection{Brand credibility}

The brand is considered one of the signs to customers aware of the quality of products or services. Therefore, for customers to trust the quality of this product or service, first, that brand must be reliable (Wernerfelt, 1988). In 1995, in the information economics theory of Herbig and Milewicz, brand credibility was also known as brand reputation. By the time, all inherent benefits, or brand characteristics, must be consistent, clearly expressed through values, beliefs, and identities (Erdem \& Swait, 1998). Besides, Erdem, Swait, and Valenzuela (2006) also did a research that brand credibility increases the perceived quality and decrease the risk of decisionmaking to customers ' brand choices, customers have thoughts and reviews that brand better than other brands. It is better than other brands (Erdem, Swait, \& Valenzuela, 2006) and improves perceived quality (Baek \& King, 2011). Ghantous $(2015,2016)$ also suggested that the importance of brand reputation, particularly in the context of services with a relatively high cognitive risk arising from the invisible nature and interactions of services... Also, Erdem and Swait (2006) determined brand credibility as the reliability of product information in the brand, requiring consumers to recognize that the brand has the capability and reliability to consistently deliver what has been promised. The evidence also shows that brand credibility increases the sense quality and reduces the cognitive risk related to customers' brand choice decisions, thereby seeing the impact of brand credibility on the customer's behavioral brand loyalty through the self-connection and brand identity.

\subsection{Self-brand connection}

Escalas and Bettman $(2003,2005)$ defined that self-brand connection is the degree to which an individual incorporates a brand into their self-concept. Studies of Cheng, White, and Chaplin (2012) also showed that consumers often integrate brands into their concepts, thereby leading to each brand being a corresponding concept that is consumed by consumers used to talk about themselves. Accidentally or not, they contribute to many levels or aggregate feelings about the user. Explaining the term 'self-concept', in 1981, Rosenberg proposed that it refers to the way consumers think and feel about who, what, and how they perceive who they are. Also, the power of self-brand connection is determined by the extent to which brands build their images and logos in the minds of users, meaning that they convey something about themselves to consumers. The credibility of a brand can impact consumers' self-connection with that brand high or low, from which brand connections will highlight the way consumers relate to the brand, feel the parallel between their personality and image with the brand and see it as a brand that expresses their lifestyle as well as expresses their personality. Since then, brand loyalty has gradually been formed.

\subsection{Brand identity}

According to Graeff (1997), brand identity is a mechanism of emotional connection between consumers and brands, it plays an important role in increasing brand satisfaction and loyalty in the relationship between a brand and a consumer. According to Stokburger Sauer et al. (2012), brand identity is described as a consumer having the same self-identifying attributes as a brand. This explanation shows that brands possess a distinct identity/personality. Consumers from 
this relationship, they express their self-image to others through the brands they are using. In this study, brand identity is considered to increase when consumers perceive a match or similarity of themselves with a product or brand. Therefore, when brands are positively evaluated, consumers will be more inclined to buy. For a brand with a strong brand identity, consumers will have higher loyalty and enthusiasm than a brand with a lower brand identity. Besides, Escalas and Bettman (2005) asserted that the brand identity is from the similarities between the brand and the consumer and that the brand itself connects as a result of the subsequent development of the process. This process allows consumers to easily distinguish themselves from others and become closer to the brand. The brand will become a link, connecting more than one icon for a customer's style; it will become an integral part of themselves.

\subsection{Brand loyalty}

Brand loyalty expresses the characteristics of consumers who have a strong commitment to the brand. It's a deep commitment to repurchasing or sponsoring a favorite product or service in the future because they see the brand as a better alternative, and this is reinforced by using a lot of times (Day, 1969; Jacoby \& Chestnut, 1978). In the current research, brand loyalty will be measured from the behavioral perspective. Behavioral loyalty refers to the repeated and systematic purchasing behavior of consumers towards a brand expressed through continuous sponsorship models and actual spending behavior (Hammondast \& Ehrenberg, 1996). The conditioning view considers behavioral measures such as the actual purchasing model to be the best indicator of brand loyalty. For reputable brands in the market, after brand recognition, consumers tend to connect themselves with the brand in a positive way. They will protect that connection, which is an important element of brand loyalty.

\section{Hypothesis development and research model}

\subsection{Brand credibility and brand loyalty}

According to Sweeney and Swait (2008), if the brand provides accurate information in the market, it will build a long-standing relationship with customers. Since then, brand loyalty will be increased by brand credibility. When customers face negative information, they will begin to doubt the brand. Therefore, brand credibility helps eliminate customer doubts when there is untrue information affecting the brand (Erdem \& Swait, 2006). The research of Alam, Arshad, and Shabbir (2012) has somewhat supported earlier studies about the relationship between brand credibility and brand loyalty. Therefore, this study hypothesizes that:

\section{H1: Brand credibility has a positive effect on brand loyalty}

\subsection{Brand identity and self-brand connection}

According to Escalas and Bettman (2005), the premise of self-brand connection is the development of the brand identity process, in which the similarity of customers and the brand is the origin of that process. Consumers distinguish themselves from others through this process. Their style is expressed through the symbol of the brand. It will become an integral part of themselves. Tuškej's proof suggested that consumers consider brands to be part of their conception (2013). Hence, the study proposes the following hypothesis:

\section{H2: Brand identity has a positive effect on the self-brand connection}

\subsection{Mediation role of self-brand connection}

Categories or brands are appraised actively, and concretely, reliably, which are more likely to be identified or connected by consumers. Dolich (1969); Chaplin and John (2005); Hankison 
(2004); Escalas and Bettman (2003) also asserted that to impart their views, consumers use trusted brands. The greater the brand credibility will raise the effect on the self-brand connection.

In 2003, Escalas and Bettman studies asserted that self-brand connection is expected to create a positive attitude and impact loyalty to that brand; consumers will maintain their relationship with the brands that are incorporated in their concepts, or other words, customers connected to a brand will lead to their loyalty to that brand. According to Oliver (1999) variables of self-brand connection are positively related to brand loyalty, so it supplies value to brands through increased purchase intent and behavior. Thereby, this study hypothesizes that: connection

H3: The relationship between brand credibility and brand loyalty is mediated by self-brand

\subsection{Mediation role of brand identity}

When consumers cope with negative publicity, they tend to defend and preserve their previously self-determined beliefs by treating negative information in a biased and defensive way (Einwiller et al., 2006). The ability to recover positive information that has previously been possible because brand identity enhances the willingness to engage in behaviors outside the consumer's role, such as courtesy, altruism (Bergami \& Bagozzi, 2000; Sen et al., 2009). According to Bhattacharya and Sen (2003), brands will be forgiven when something goes wrong. Brand credibility provides reliable information about the products in a brand, such as the place of production or the quality of the products. Besides, Stokburger-Sauer et al. (2012) indicated that brands have different characteristics from competitors will be more likely to be identified by consumers because those brands satisfy the demands of consumers (Erdem \& Swait, 2006). Besides, Stokburger-Sauer et al. (2012) indicated that brands have different characteristics from competitors will be more likely to be identified by consumers because those brands satisfy the demands of consumers. From there, the research suggests the hypothesis that:

H4: The relationship between brand credibility and brand loyalty is mediated by brand identity

From previous studies, this paper proposes the following research model:

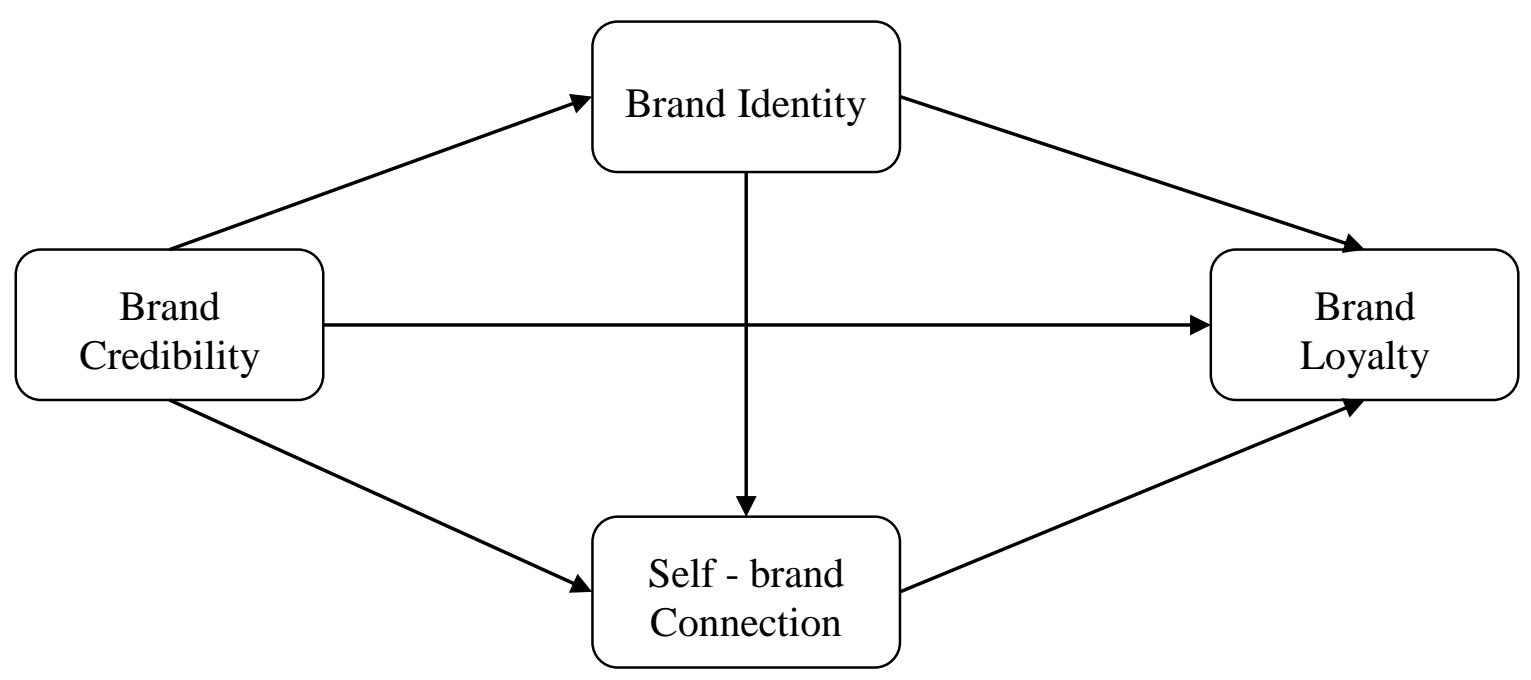

Figure 1. Proposed research model 


\section{Methodology}

\subsection{Measurement items}

The constructs used in this research were elaborated based on widely accepted multi-item scales developed from the previous literature. The research model comprised four major constructs (1) Brand credibility, (2) Self-brand connection, (3) Brand identity, (4) Brand loyalty. Brand credibility was measured with six items adopted from Dwivedi, Nayeem, and Murshed (2018); del Barrio-García and Prados-Peña (2019). There were six items used to measure for brand identity and adopted from Popp and Woratschek (2017); Rather (2018). The Self-brand connection was measured with five items adapted from Van der Westhuizen (2018), Berger, Sprott, and Herrmann (2017); Harrigan, Evers, Miles, and Daly (2018). Finally, the measurement scales of Brand loyalty were adopted from Foroudi, Jin, Gupta, Foroudi, and Kitchen (2018); Nam, Ekinci, and Whyatt (2011); Leckie, Nyadzayo, and Johnson (2017) which included seven items. This study used a 7point Likert scale, ranging from 1- strongly disagree to 7- strongly agree. A neutral response "neither disagree nor agree" was adopted to reduce uninformed responses. Lewis (1993) found that the 7-point scale produced stronger correlations, so the results will be more accurate.

\subsection{Sampling and data collection procedure}

According to Gorsuch (1983), determining factor analysis should be at least 50. Nguyen (2011) suggested that the size of the sample is equal or more than $n * 5$ (n: items). Hoang Trong and Chu (2005) also suggested that when trying to determine the size of the sample for conventional EFA factor analysis, the size of the sample must be at least 4 or 5 times the number of observed variables. Thus, with 24 items are measured by seven-point Likert-type scales, the minimum size of the sample was $\mathrm{n}=120(24 * 5)$.

This research used probability sampling and non-probability sampling methods. In the nonprobability sampling method, the quota sampling and convenience sampling methods have been used to collect data. Quota sampling helps determine the number of participants in the survey, ensuring the desired accuracy of different groups of students and office workers in a collective based on appropriate sample characteristics. Besides, this study also uses a convenience sampling method relying on the ease of approach of respondents, which saves time and costs during the survey. Students and office workers are the main subjects of this study because they are a large audience in Vietnam's age scale. That is also the object of the affordability and the need to buy the most Apple products. According to Cooper and Schindler (2006), the questionnaire is an effective way to collect data when researchers know exactly what to investigate and how to measure variables to get accurate and appropriate results. This paper uses questionnaires built on the development of a scale of variables. The scales are translated from specialized journals and refer to the previously researched results to set up the interview questionnaire. Before collecting data, researchers piloted a survey questionnaire by randomly selecting 20 students and office workers. This step helps identify sentences that confuse participants. Since then, the questionnaire was built with high reliability and best completed before the survey.

The research model was examined with data from 420 students and office workers in universities in Ho Chi Minh City. At the same time, a direct survey was carried out at 7 Universities in Ho Chi Minh city. Seven universities were selected at random.

\section{Result}

The result obtained 420 results. Of these, $74 \%$ of answers were collected from direct surveys and $26 \%$ of answers from online surveys. Inappropriate questions have been removed 
because they have no honest answers, or they are not subject to research. Finally, a total of 308 answers were used for data analysis.

Through the descriptive statistical analysis, about the occupation, the respondents included 246 students, accounting for $80 \%$ of the total and 62 office workers, accounting for $20 \%$ of the total, consistent with the research objectives. assist. Of the 308 respondents, $100 \%$ are using Apple products, 192 are female (62\%), 109 are male (33\%), 14 are of another gender (14\%).

In terms of age, many respondents belong to the age group of 18 - 29 years old with $93 \%$. The second group is 30-39 years old with 5\%. The remaining group accounted for $2 \%$ of people over 39 years old. In terms of income (unit: million VND), the income group accounts for the majority of the respondents who are below 10 with over $80 \%$. The second group ranges from more than 10 to 25 accounting for $14 \%$. Other groups ranged from 25 to 50 and from 50 to 100 and more than 100 accounted for $4 \%, 0 \%$, and $1 \%$ respectively.

\section{Analyzing reliability of scale - Cronbach from Alpha, Testing convergent values, discriminant values, and general reliability}

Cronbach's Alpha coefficients are used to conditions for the scale to meet the requirements: (1) the standardized regression weight (Standardized Regression Weight) of observed variables must be greater than 0.5 ; (2) extracted variance (AVE) not less than eliminate inappropriate variables. The condition for Cronbach's Alpha test is that the observed variables with a total correlation coefficient of less than 0.3 will be disqualified and the criteria for choosing a scale when Cronbach's Alpha is 0.6 or higher (Nunnally \& Bernstein, 1994) and Testing converged values, discriminant values, and general reliability (Construct Validity) for each concept. According to Hair, Black, Babin, Anderson, and Tatham (2010), the 0.5; (3) Composite reliability (CR) must be greater than 0.7 . The results are shown in Table 1.

\section{Table 1}

Cronbach's Alpha, AVE and CE

\begin{tabular}{|c|c|c|c|c|}
\hline Items & Number of items & Cronbach Alpha & CR & AVE \\
\hline BC & 6 & 0,899 & 0,855 & 0,663 \\
\hline SBC & 5 & 0,918 & 0,905 & 0,762 \\
\hline SBI & 6 & 0,927 & 0,927 & 0,810 \\
\hline BLy & 7 & 0,937 & 0,930 & 0,769 \\
\hline
\end{tabular}

Source: Data analysis result of the research

\section{Analysis of the CFA model}

The first CFA test has the results such as CMIN / $\mathrm{df}=4,325 \mathrm{did}$ not meet the condition of less than $3, \mathrm{CFI}=0,887$ did not meet the condition greater than 0.9 ; and TLI $=0,871(<0.9)$ did not meet the condition greater than 0.9, RMSEA $=0,104$ did not meet the condition greater than 0.08 , GFI $=0,792(<0.8)$ did not satisfy the condition. This study adjusted the small and big weighted variables to improve the indexes. After the 12 variable observations (SBI4, SBI5, SBI6, BLy1, BLy2, BLy4, BC1, BC5, BC6, SBC1, SBC4, SBC5).

Thus, after the last CFA analysis, there were 13 observation variables, brand identity (3 observation variables), brand credibility (3 observation variables), self-brand connection (3 observation variables), and brand loyalty (4 observation variables). The CFA results shown in Table 4 indicate that the conformance evaluation indicators of the model were fit and comfort with the context of Vietnam. 


\section{Table 2}

CFA analysis result

\begin{tabular}{|l|c|c|c|}
\hline \multicolumn{1}{|c|}{ Evaluation table of measurement indicators } & Condition & CFA & Evaluate \\
\hline CMIN/df & $\leq 3$ & 2,545 & Pass \\
\hline Goodness of Fit index (GFI) & $\geq 0,9$ & 0,935 & Pass \\
\hline Tucker Lewis Index (TLI) & $\geq 0,9$ & 0,962 & Pass \\
\hline Comparative Fit Index (CFI) & $\geq 0,9$ & 0,972 & Pass \\
\hline $\begin{array}{l}\text { Root Mean Square Error of Approximation } \\
\text { (RMSEA) }\end{array}$ & $\leq 0,08$ & 0,071 & Pass \\
\hline
\end{tabular}

Source: Data analysis result of the research

\section{Analysis of SEM Model}

To test relationships in the research model and test the hypotheses, the linear SEM model is used. After running AMOS, the SEM model was applied. The fit tests of the model are shown in the table. The model was considered to be suitable for market data when there were TLI, CFI 0.9, CMIN/df 3, GFI 0.08, and RMSEA 0.08. At the first run we can see that the CMIN/df $=2,545>$ $0.3, \mathrm{CFI}=0,972>0.9, \mathrm{TLI}=0,962<0.9, \mathrm{RMSEA}=0,071<0.08, \mathrm{GFI}=0,935$, all have reached the permitted level.

In the first SEM run, the indicators show that the linear structure model is consistent with market data. In particular, the RMSEA $=0,071<0.08$ indicates that this is a relatively good model.

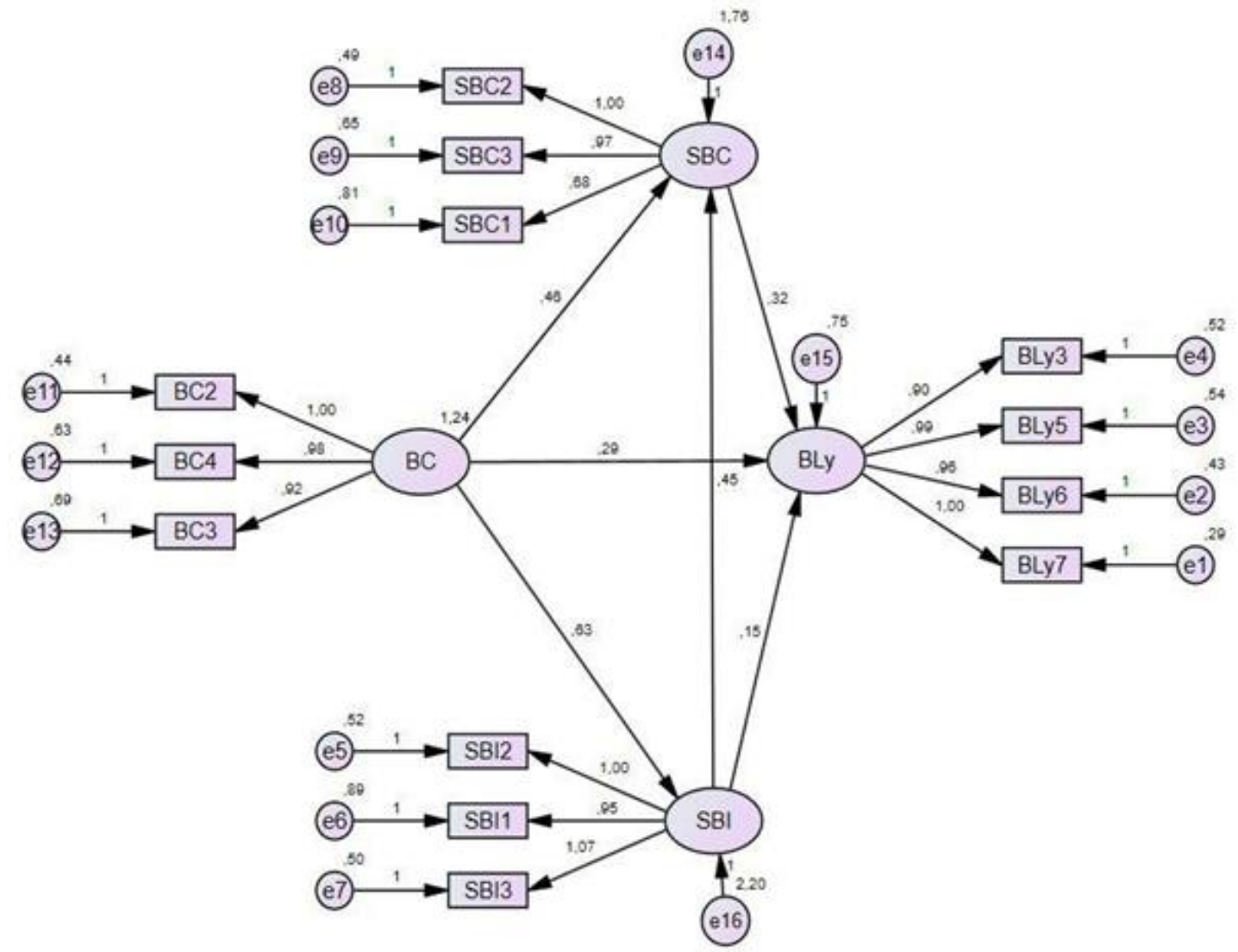

Figure 2. SEM result 
Bootstrap is a finite sampling method developed by Efron (1979). This is a repetitive sampling method that replaces the original sample, in which the prototype plays the role of a crowd (Schumacher \& Lomax, 1996). Testing the bootstrap will help the team assess the sustainability of the model. The difference in the bootstrap estimate with the smaller sample shows the reliability of the calculated sample.

Table 3

Regression analysis

\begin{tabular}{|c|c|c|c|c|c|c|}
\hline \multicolumn{7}{|c|}{ Regression Weights: (Group number 1 - Default model) } \\
\hline \multicolumn{3}{|c|}{ Parameter } & \multirow{2}{*}{$\begin{array}{c}\text { Estimate } \\
, 633\end{array}$} & \multirow{2}{*}{$\begin{array}{c}\text { Lower } \\
, 091\end{array}$} & \multirow{2}{*}{$\frac{\text { Upper }}{6,948}$} & \multirow{2}{*}{$\frac{\mathbf{P}}{* * *}$} \\
\hline SBI & $<---$ & $\mathrm{BC}$ & & & & \\
\hline SBC & $<---$ & $\mathrm{BC}$ & ,458 & ,093 & 4,952 & $* * *$ \\
\hline $\mathrm{SBC}$ & $<---$ & SBI & 454 &, 061 & 7,506 & $* * *$ \\
\hline BLy & $<--$ & $\mathrm{SBC}$ & ,318 & ,046 & 6,950 & $* * *$ \\
\hline BLy & $<---$ & SBI & 153 & 044 & 3,449 & $* * *$ \\
\hline BLy & $<--$ & $\mathrm{BC}$ & 290 & 065 & 4,452 & $* * *$ \\
\hline BLy7 & $<---$ & BLy & 1,000 & & & \\
\hline BLy6 & $<--$ & BLy & 960 & ,041 & 23,654 & $* * *$ \\
\hline BLy5 & $<---$ & BLy & ,994 & ,044 & 22,727 & $* * *$ \\
\hline BLy3 & $<---$ & BLy & ,899 &, 042 & 21,527 & $* * *$ \\
\hline $\mathrm{SBI} 2$ & $<---$ & SBI & 1,000 & & & \\
\hline SBI1 & $<---$ & SBI & ,951 & ,043 & 21,870 & $* * *$ \\
\hline SBI3 & $<---$ & SBI & 1,069 &, 042 & 25,729 & $* * *$ \\
\hline SBC2 & $<--$ & $\mathrm{SBC}$ & 1,000 & & & \\
\hline SBC3 & $<---$ & SBC & ,968 & ,041 & 23,363 & $* * *$ \\
\hline SBC1 & $<---$ & $\mathrm{SBC}$ & ,675 & ,037 & 18,302 & $* * *$ \\
\hline $\mathrm{BC} 2$ & $<---$ & $\mathrm{BC}$ & 1,000 & & & \\
\hline $\mathrm{BC} 4$ & $<---$ & $\mathrm{BC}$ & 977 & ,065 & 15,140 & $* * *$ \\
\hline BC3 & $<---$ & $\mathrm{BC}$ & ,917 & ,063 & 14,578 & $* * *$ \\
\hline
\end{tabular}

Source: Data analysis result of the research

Based on the results from the significance level column (P) in Table 3, if any relationship had a p-value of $<0.05$, then it would be statistically significant. In contrast, if any relationship had p-value $>0.05$, it was not statistically significant. While factors such as self-brand connection and brand credibility have a positive impact on brand loyalty. Brand identity is not much impact on brand loyalty. This can be explained that when brands create credibility with customers and customers are connected to the products of the business. Customers easily generate brand loyalty. 
The above results also show that the brand credibility impacts on brand identity and selfbrand connection. And brand identity will have a positive impact on a self-brand connection. These impact relationships will be explained more clearly in the hypothesis test.

\section{Discussion}

The research results are fit with previous studies when pointing out the indirect effect of brand credibility through intermediate variables to brand loyalty. The brand is one of the customers' awareness of the quality of products or services. Therefore, for customers to trust the quality of this product or service, the brand must first be reputable (Wernerfelt, 1988). By providing reliable information to consumers about the quality of the brand, thereby seeing a remarkable position of the brand (Erdem \& Swait, 2006; Leisching et al., 2012). Moreover, Stokburger-Sauer et al. (2012) indicated that brands that have distinct characteristics from competitors will be more likely to be identified by consumers because those brands meet demand. of consumers. Brand credibility is one of the most important factors to brand identity (Harley, 1985; Ruth, 2001).

Escalas and Bettman (2005) have asserted that brand identity comes from the similarity between consumers and the brand. And the self-brand connection is the result of the further development of this process. Research results show that the similarity between customers and consumers will have positive effects on brand self-connection. This shows that it is like the link between consumers and the brand, the more similar the more connected.

In 2014, Banister and Cocker argued that consumers adopt the brands they buy to express the personal style they want to build. Help them express their values, personality, and lifestyle through self-brand connections. Based on research, consumers' strong connection to the brand is a key to build brand loyalty. It positively is self-connectivity and consumers tend to protect that connection. According to the results of the study, the impact of self-brand connection to brand loyalty is the highest value, showing the strong connection between the two factors.

Also, the scope of this paper shows poorer results than previous studies. First, according to the studies of Gilovich et al. (2015), consumers can identify or connect with one or more brands that are evaluated more positively and reliably.

However, the results show that the influence of brand credibility factors on the self-brand connection is not strong. Second, brand credibility increases the reliability of quality, reduce perceived risks, lesser information costs (Erdem \& Swait, 1998). However, Sweeney and Swait (2008) argued that if the brand provides accurate information in the market, it will build a longstanding relationship with customers. The above argument has supported the results of this research with the fact that reputation to brand loyalty requires a long process and needs more intermediate effects. Finally, the research results of Stokburger-Sauer et al. (2012) have confirmed that positive brand identity can turn customers into brand loyalists and prevent consumers from moving to other brands. From there, see that brand identity is positively related to brand loyalty. However, at present, there may be many impact factors that make it difficult for customers to switch from brand identity to brand loyalty. That means brand loyalty is less enhanced by brand identity.

\section{Managerial implication}

In theory, this study clarifies the role that factors play in brand loyalty. It is not directly affected by brand credibility but indirectly by brand identity and brand self-connection. When a brand has high credibility, the ability to identify high, thereby promoting the self-connection of 
the brand with consumers. A self-brand connection will increase the loyalty of consumers to the brand. Therefore, it is necessary to promote intermediate factors. This study also helps businesses to have more ways to reach customers in the context of building a good brand image, creating sympathy, a high reputation, and trying to connect the brand image of the company to themself with the image of your business brand. Since then, businesses will have many loyal customers not only buying products and services from customers but also loyal in mind, thought - is a very valuable asset of the brand. Practically, this research will help businesses increase their brand loyalty. Businesses must create momentum from brands' credibility to promote brand loyalty. Besides, it should be combined with customer insight and innovation. In addition, the theory can also be applied in social, educational, and medical categories, etc. when prestige will create a premise for the transition to behavioral loyalty.

\section{Conclusion}

This study is clear of the impact of brand credibility, self-brand connection, and brand identity on the brand loyalty of consumers. From there, helping businesses can identify what are the main factors that strongly affect brand loyalty. Based on the available strengths of the business, it creates the prestige of the brand. From there, businesses can offer solutions that enhance behavioral loyalty when developing the connection between target customers and products through the level of the brand identity of customers. The role of credibility and loyalty is an indirect factor acting through 2 intermediary factors.

\section{Limitations and future research directions}

In addition to the results, the research also has the following limitations and future research directions: 1) Time limit of 6 months, limited access space in 7 universities, 2) Number of the sample surveyed limitations due to low funding and narrow research scope, 3) Not being able to reach the maximum of Apple's target customers when only studying students and office workers at 7 universities, 4) Only possible Quantitative research approach. Through the above limitations, the research director for the future topic is to expand the scope and scope of the research to have a more general view of social dimensions and new variables that may affect the heart brand loyalty or not.

\section{References}

Aaker, J. L. (1999). The malleable self: The role of self-expression in persuasion. Journal of Marketing Research, 36(1), 45-57. doi:10.1177/002224379903600104

Abimbola, T., Trueman, M., Iglesias, O., Liu, F., Li, J., Mizerski, D., \& Soh, H. (2012). Selfcongruity, brand attitude, and brand loyalty: A study on luxury brands. European Journal of Marketing, 46(7), 922-937. doi:10.1108/03090561211230098

Alam, A., Arshad, M. U., \& Shabbir, S. A. (2012). Brand credibility, customer loyalty and the role of religious orientation. Asia Pacific Journal of Marketing and Logistics, 24(4), 583-598. doi:10.1108/13555851211259034

Alnawas, I., \& Altarifi, S. (2016). Exploring the role of brand identification and brand love in generating higher levels of brand loyalty. Journal of Vacation Marketing, 22(2), 111-128. doi:10.1177/1356766715604663

An, J., Do, D. K. X., Ngo, L. V., \& Quan, T. H. M. (2019). Turning brand credibility into positive word-of-mouth: Integrating the signaling and social identity perspectives. Journal of Brand Management, 26(2), 157-175. doi:10.1057/s41262-018-0118-0 
Aziz, N. A. (2018). The influence of coproduction's factors and corporate image toward attitudinal loyalty. Journal of Islamic Marketing, 9(2), 421-438. doi:10.1108/JIMA-10-2016-0080

Baek, T. H., \& King, K. W. (2011). Exploring the consequences of brand credibility in services. Journal of Services Marketing, 25(4), 260-272. doi:10.1108/08876041111143096

Banister, E. N., \& Cocker, H. L. (2014). A cultural exploration of consumers' interactions and relationships with celebrities. Journal of Marketing Management, 30(1/2), 1-29. doi:10.1080/0267257X.2013.807863

Bergami, M., \& Bagozzi, R. P. (2000). Self-categorization, affective commitment and group selfesteem as distinct aspects of social identity in the organization. British Journal of Social Psychology, 39(4), 555-577. doi:10.1348/014466600164633

Berger, A., Schlager, T., Sprott, D. E., \& Herrmann, A. (2017). Gamified interactions: Whether, when, and how games facilitate self-brand connections. Journal of the Academy of Marketing Science, 46(4), 652-673. doi:10.1007/s11747-017-0530-0

Bhattacharya, C. B., \& Sen, S. (2003). Consumer-company identification: A framework for understanding consumers' relationships with companies. Journal of Marketing, 67(2), 7688. doi:10.1509/jmkg.67.2.76.18609

Chaplin, L. N., \& John, D. R. (2005). The development of self-brand connections in children and adolescents. Journal of Consumer Research, 32(1), 119-129. doi:10.1086/426622

Cheng, S. Y., White, T. B., \& Chaplin, L. N. (2012). The effects of self-brand connections on responses to brand failure: A new look at the consumer-brand relationship. Journal of Consumer Psychology, 22(2), 280-288. doi:10.1016/j.jcps.2011.05.005

Cooper, D. R., Schindler, P. S., \& Sun, J. (2006). Business research methods (12th ed.). New York, NY: McGraw-Hill.

Dalman, M. D., Buche, M. W., \& Min, J. (2019). The differential influence of identification on ethical judgment: The role of brand love. Journal of Business Ethics, 158(3), 875-891. doi:10.1007/s10551-017-3774-1

Day, G. S. (1969). A two-dimensional concept of brand loyalty. Journal of Advertising Research, 9(3), 29-35.

del Barrio-García, S., \& Prados-Peña, M. B. (2019). Do brand authenticity and brand credibility facilitate brand equity? The case of heritage destination brand extension. Journal of Destination Marketing \& Management, 13, 10-23. doi:10.1016/j.jdmm.2019.05.002

Dolich, I. J. (1969). Congruence relationships between self images and product brands. Journal of marketing research, 6(1), 80-84. doi:10.1177/002224376900600109

Dwivedi, A. (2015). A higher-order model of consumer brand engagement and its impact on loyalty intentions. Journal of Retailing and Consumer Services, 24, 100-109. doi:10.1016/j.jretconser.2015.02.007

Dwivedi, A., Nayeem, T., \& Murshed, F. (2018). Brand experience and consumers' WillingnessTo-Pay (WTP) a price premium: Mediating role of brand credibility and perceived uniqueness. Journal of Retailing and Consumer Services, 44(C), 100-107. doi:10.1016/j.jretconser.2018.06.009 
Efron, B. (1979). Bootstrap methods: Another look at the jackknife. Annals of Statistics, 7(1), 1-26.

Einwiller, S. A., Fedorikhin, A., Johnson, A. R., \& Kamins, M. A. (2006). Enough is enough! When identification no longer prevents negative corporate associations. Journal of the Academy of Marketing Science, 34(2), 185-194. doi:10.1177/0092070305284983

Elbedweihy, A. M., Jayawardhena, C., Elsharnouby, M. H., \& Elsharnouby, T. H. (2016). Customer relationship building: The role of brand attractiveness and consumer-brand identification. Journal of Business Research, Elsevier, 69(8), 2901-2910. doi:10.1016/j.jbusres.2015.12.059

Erdem, T., \& Swait, J. (1998). Brand equity as a signaling phenomenon. Journal of Consumer Psychology, 7(2), 131-157. doi:10.1207/s15327663jcp0702_02

Erdem, T., Swait, J., \& Valenzuela, A. (2006). Brands as signals: A cross-country validation study. Journal of Marketing, 70(1), 34-49. doi:10.1509/jmkg.70.1.034.qxd

Escalas, J. E., \& Bettman, J. R. (2003). You are what they eat: The influence of reference groups on consumers' connections to brands. Journal of Consumer Psychology, 13(3), 339-348. doi:10.1207/S15327663JCP1303_14

Escalas, J. E., \& Bettman, J. R. (2005). Self-construal, reference groups, and brand meaning. Journal of Consumer Research, 32(3), 378-389. doi:10.1086/497549

Foroudi, P., Jin, Z., Gupta, S., Foroudi, M. M., \& Kitchen, P. J. (2018). Perceptional components of brand equity: Configuring the symmetrical and asymmetrical paths to brand loyalty and brand purchase intention. Journal of Business Research, 89, 462-474. doi:10.1016/j.jbusres.2018.01.031

Ghantous, N. (2015). Re-examining encounter intensity's conceptualisation, measurement and role. The Service Industries Journal, 35(5), 237-254. doi:10.1080/02642069.2015.1002479

Ghantous, N. (2016). The impact of services brand personality on consumer-brand relationship quality. Services Marketing Quarterly, 37(3), 185-199. doi:10.1080/15332969.2016.1184544

Gilovich, T., Kumar, A., \& Jampol, L. (2015). A wonderful life: Experiential consumption and the pursuit of happiness. Journal of Consumer Psychology, 25(1), 152-165. doi:10.1016/j.jcps.2014.08.004

Gorsuch, R. L. (1983). Factor analysis (2nd ed.). Hillsdale, NJ: Lawrence Erlbaum Associates.

Graeff, T. R. (1996). Using promotional messages to manage the effects of brand and self-image on brand evaluations. Journal of Consumer Marketing, 13(3), 4-18. doi:10.1108/07363769610118921

Graeff, T. R. (1997). Consumption situations and the effects of brand image on consumers' brand evaluations. Psychology \& Marketing, 14(1), 49-70. doi:10.1002/(SICI)15206793(199701)14:1<49::AID-MAR4>3.0.CO;2-O

Grubb, E. L., \& Grathwohl, H. L. (1967). Consumer self-concept, symbolism and market behavior: A theoretical approach. Journal of Marketing, 31(4), 22-27. doi:10.1177/002224296703100405

Hair, J. F., Black, W. C., Babin, B. J., Anderson, R. E., \& Tatham, R. L. (1998). Multivariate data analysis. Upper Saddle River, NJ: Prentice hall. 
Hair, J. F., Black, W. C., Babin, B. J., Anderson, R. E., \& Tatham, R. L. (2010). Multivariate data analysis (7th ed.). Upper Saddle River, NJ: Pearson Prentice Hall.

Haley, R. I. (1985). Developing effective communications strategy: A benefit segmentation approach. New York, NY: Ronald Press.

Hammond, K., East, R., \& Ehrenberg, A. (1996). Buying more and buying longer: Concepts and applications of consumer loyalty. London, UK: London Business School.

Hankinson, G. (2004). The brand images of tourism destinations: a study of the saliency of organic images. Journal of Product \& Brand Management, 13(1), 6-14. doi:10.1108/10610420410523803

Harrigan, P., Evers, U., Miles, M. P., \& Daly, T. (2018). Customer engagement and the relationship between involvement, engagement, self-brand connection and brand usage intent. Journal of Business Research, 88, 388-396. doi:10.1016/j.jbusres.2017.11.046

Hatcher, P. J., Hulme, C., \& Ellis, A. W. (1994). Ameliorating early reading failure by integrating the teaching of reading and phonological skills: The phonological linkage hypothesis. Child Development, 65(1), 41-57. doi:10.1111/j.1467-8624.1994.tb00733.x

He, H., Li, Y., \& Harris, L. (2012). Social identity perspective on brand loyalty. Journal of Business Research, 65(5), 648-657. doi:10.1016/j.jbusres.2011.03.007

Hemsley-Brown, J., \& Alnawas, I. (2016). Service quality and brand loyalty. International Journal of Contemporary Hospitality Management, 28(12), 2771-2794. doi:10.1108/IJCHM-092015-0466

Herbig, P., \& Milewicz, J. (1995). The relationship of reputation and credibility to brand success. Journal of Consumer Marketing, 12(4), 5-11.

Hoang Trong \& Chu, N. N. M. (2008). Phân tích dĩu liệu nghiên cúu SPSS (Tập 2) [Analysis of SPSS research data (Vol. 2)]. Hanoi, Vietnam: NXB Hồng Đức.

Iglesias, O., Singh, J. J., \& Batista-Foguet, J. M. (2011). The role of brand experience and affective commitment in determining brand loyalty. Journal of Brand Management, 18(8), 570-582. doi:10.1057/bm.2010.58

Jacoby, J., \& Chestnut, R. W. (1978). Brand loyalty: Measurement and management. New York, NY: John Wiley \& Sons.

Jin, C. H. (2018). The effects of Creating Shared Value (CSV) on the consumer self-brand connection: Perspective of sustainable development. Corporate Social Responsibility and Environmental Management, 25(6), 1246-1257. doi:10.1002/csr.1635

Kuo, Y. F., \& Hou, J. R. (2014). Which brand will you not select? Investigating oppositional brand loyalty from the perspectives on social identity theory and emotions. Proceedings of the 12th International Conference on Advances in Mobile Computing and Multimedia, 421-427. doi:10.1145/2684103.2684167

Lam, D. N. (2006). Giáo trình nghiên cưu marketing [Marketing research curriculum]. Khoa Marketing, Trường Đại Học Marketing, Ho Chi Minh City, Vietnam.

Le, H. V. (2015). Phưong pháp nghiên cúu khoa hoc [Scientific research methods]. Trường Đại Học Nha Trang, Nha Trang, Vietnam. 
Leckie, C., Nyadzayo, M. W., \& Johnson, L. W. (2016). Antecedents of consumer brand engagement and brand loyalty. Journal of Marketing Management, 32(5/6), 558-578. doi:10.1080/0267257X.2015.1131735

Leischnig, A., Geigenmüller, A., \& Enke, M. (2012). Brands you can rely on! An empirical investigation of brand credibility in services. Schmalenbach Business Review, 64(1), 44-58. doi:10.1007/BF03396837

Levy, S. J. (1959). Symbols for sale. Brighton, MA: Harvard business review.

Lewis Jr, W. M. (1993). The ecological sciences and the public domain. University of Colorado Law Review, 65, 279-292.

Malhotra, N. K. (1988). Self-concept and product choice: An integrated perspective. Journal of Economic Psychology, 9(1), 1-28. doi:10.1016/0167-4870(88)90029-3

Martin, F., \& Tao-Peng, F. (2017). Morality matters? Consumer identification with celebrity endorsers in China. Asian Business \& Management, 16(4/5), 272-289. doi:10.1057/s41291017-0022-6

Moliner, M. Á., Monferrer-Tirado, D., \& Estrada-Guillén, M. (2018). Consequences of customer engagement and customer self-brand connection. Journal of Services Marketing, 32(4), 387399. doi:10.1108/JSM-08-2016-0320

Nam, J., Ekinci, Y., \& Whyatt, G. (2011). Brand equity, brand loyalty and consumer satisfaction. Annals of tourism Research, 38(3), 1009-1030. doi:10.1016/j.annals.2011.01.015

Nguyen, T. D. (2011). Phương pháp nghiên cưu khoa học trong kinh doanh - Thiết kế và thưc hiện [Methods of scientific research in business - Design and implementation]. Hanoi, Vietnam: NXB Lao động Xã hội.

Nunnally, J. C., \& Bernstein, I. H. (1994). Psychometric theory (3rd ed.). New York, NY: Tata McGraw-Hill Education.

Oliver, R. L. (1999). Whence consumer loyalty? Journal of Marketing, 63, 33-34.

Popp, B., \& Woratschek, H. (2017). Consumer-brand identification revisited: An integrative framework of brand identification, customer satisfaction, and price image and their role for brand loyalty and word of mouth. Journal of Brand Management, 24(3), 250-270. doi:10.1057/s41262-017-0033-9

Rather, R. A. (2018). Investigating the impact of customer brand identification on hospitality brand loyalty: A social identity perspective. Journal of Hospitality Marketing \& Management, 27(5), 487-513. doi:10.1080/19368623.2018.1404539

Rosenberg, M. (1981). The self-concept: Social product and social force. In M. Rosenberg \& R. H. Turner (Eds.), Social psychology: Sociological perspectives (pp. 593-624). New York, NY: Basic Books.

Rosenberg, M. (1989). Self-concept research: A historical overview. Social Forces, 68(1), 34-44.

Ruth, J. A. (2001). Promoting a brand's emotion benefits: The influence of emotion categorization processes on consumer evaluations. Journal of Consumer Psychology, 11(2), 99-113. doi:10.1207/S15327663JCP1102_03

Schumacker, R. E., \& Lomax, R. G. (1996). A beginner's guide to structural equation modeling. Mahwah, NJ: Lawrence Erlbaum Associates, Inc. 
Schumacker, R. E., \& Lomax, R. G. (2004). A beginner's guide to structural equation modeling (2nd ed.) London, UK: Psychology Press.

Sen, S., Du, S., \& Bhattacharya, C. B. (2009). Building brand relationships through corporate social responsibility. In Handbook of brand relationships (pp. 217-233). London, UK: Routledge.

Sirgy, M. J. (1980). Towards a psychological model of consumer satisfaction/dissatisfaction. Proceeding of the Consumer Satisfaction/Dissatisfaction \& Complaining Behavior, New Findings on Consumer Satisfaction and Complaining, November 6-8, 40-47.

Sirgy, M. J. (1982). Self-concept in consumer behavior: A critical review. Journal of Consumer Research, 9(3), 287-300. doi:10.1086/208924

Sirgy, M. J. (2015). The self-concept in relation to product preference and purchase intention. In V. Bellur (Ed.), Marketing horizons: A 1980's perspective. Developments in marketing science: Proceedings of the academy of marketing science (pp. 350-354). Cham, Switzerland: Springer. doi:10.1007/978-3-319-10966-4_94

Sirgy, M. J. (2018). Self-congruity theory in consumer behavior: A little history. Journal of Global Scholars of Marketing Science, 28(2), 197-207. doi:10.1080/21639159.2018.1436981

Sirgy, M. J., \& Samli, A. C. (1985). A path analytic model of store loyalty involving self-concept, store image, geographic loyalty, and socioeconomic status. Journal of the Academy of Marketing Science, 13(3), 265-291. doi:10.1007/BF02729950

Steenkamp, J. B. E., \& Van Trijp, H. C. (1991). The use of LISREL in validating marketing constructs. International Journal of Research in marketing, 8(4), 283-299. doi:10.1016/0167-8116(91)90027-5

Stokburger-Sauer, N., Ratneshwar, S., \& Sen, S. (2012). Drivers of consumer-brand identification. International Journal of Research in Marketing, 29(4), 406-418. doi:10.1016/j.ijresmar.2012.06.001

Suki, J. S. N. M., \& Sasmita, J. (2015). Young consumers' insights on brand equity: Effects of brand association, brand loyalty, brand awareness, and brand image. International Journal of Retail \& Distribution Management, 43(3), 276-292. doi:10.1108/IJRDM-02-2014-0024

Swait, J. (2004). Brand credibility, brand consideration, and choice. Journal of Consumer Research, 31(1), 191-198. doi:10.1086/383434

Sweeney, J., \& Swait, J. (2008). The effects of brand credibility on customer loyalty. Journal of retailing and consumer services, 15(3), 179-193. doi:10.1016/j.jretconser.2007.04.001

Todd, S. (2001). Self-concept: A tourism application. Journal of Consumer Behaviour: An International Research Review, 1(2), 184-196. doi:10.1002/cb.64

Tuškej, U., Golob, U., \& Podnar, K. (2013). The role of consumer-brand identification in building brand relationships. Journal of Business Research, 66(1), 53-59. doi:10.1016/j.jbusres.2011.07.022

Van der Westhuizen, L. M. (2018). Brand loyalty: Exploring self-brand connection and brand experience. Journal of Product \& Brand Management, 27(2), 172-184. doi:10.1108/JPBM07-2016-1281 
Wernerfelt, B. (1988). Umbrella branding as a signal of new product quality: An example of signalling by posting a bond. The RAND Journal of Economics, 19(3), 458-466. doi: $10.2307 / 2555667$

Zikmund, W. G., McLeod, R., \& Gilbert, F. W. (2003). Customer relationship management: Integrating marketing strategy and information technology. Hoboken, NJ: Wiley.

APPENDIX

\begin{tabular}{|c|c|c|c|}
\hline STT & The major constructs & Measurement items & Researchers \\
\hline \multirow{6}{*}{1} & \multirow{6}{*}{ Brand credibility } & Apple - the brand you can trust & \multirow{4}{*}{$\begin{array}{l}\text { Dwivedi, Nayeem, and } \\
\text { Murshed (2018) }\end{array}$} \\
\hline & & $\begin{array}{l}\text { Apple has capable of delivering } \\
\text { what it says to its customers. }\end{array}$ & \\
\hline & & $\begin{array}{l}\text { At any time, my brand experiences } \\
\text { of Apple gives me the expectation } \\
\text { that the products are created exactly } \\
\text { as advertised. }\end{array}$ & \\
\hline & & $\begin{array}{l}\text { Apple owns quality products and } \\
\text { the developer publicly discloses the } \\
\text { technology to the customer. }\end{array}$ & \\
\hline & & I see Apple as a credible brand & \multirow{2}{*}{$\begin{array}{l}\text { del Barrio-García, and } \\
\text { Prados-Peña (2019) }\end{array}$} \\
\hline & & I see Apple as a persuasive brand & \\
\hline \multirow{6}{*}{2} & \multirow{6}{*}{ Brand identity } & $\begin{array}{l}\text { I feel like I was offended when } \\
\text { someone criticized Apple }\end{array}$ & \multirow[t]{3}{*}{ Rather (2017) } \\
\hline & & Apple's successes are my successes. & \\
\hline & & $\begin{array}{l}\text { When someone praises Apple, I feel } \\
\text { like a personal compliment }\end{array}$ & \\
\hline & & Apple as I am and who I want to be. & \multirow[t]{3}{*}{ Banister and Cocker (2014) } \\
\hline & & $\begin{array}{l}\text { Apple plays an important and } \\
\text { indispensable in my life }\end{array}$ & \\
\hline & & Apple represents what I believe. & \\
\hline \multirow{4}{*}{3} & \multirow{4}{*}{ Self-brand connection } & $\begin{array}{l}\text { When using Apple's high-tech and } \\
\text { modern product lines, I feel like a } \\
\text { person of technology and } \\
\text { modernity. }\end{array}$ & \multirow[t]{4}{*}{$\begin{array}{l}\text { Van der Westhuizen } \\
(2018) ; \text { Harrigan et al. } \\
\text { (2018); Berger et al. (2017) }\end{array}$} \\
\hline & & $\begin{array}{l}\text { Using the Apple brand's product } \\
\text { helps me to show the position of } \\
\text { myself to everyone around me. }\end{array}$ & \\
\hline & & $\begin{array}{l}\text { I think Apple (can) enhance the } \\
\text { personality and personal style that I } \\
\text { create (Sprott et al 2009). }\end{array}$ & \\
\hline & & $\begin{array}{l}\text { Brand Apple contributes to } \\
\text { enriched my life. }\end{array}$ & \\
\hline
\end{tabular}




\begin{tabular}{|c|c|c|c|}
\hline STT & The major constructs & Measurement items & Researchers \\
\hline & & $\begin{array}{l}\text { Brand Apple helps me orient myself } \\
\text { in the future. }\end{array}$ & \\
\hline \multirow{7}{*}{4} & \multirow{7}{*}{ Brand loyalty } & $\begin{array}{l}\text { From the same features of the } \\
\text { utility, I am willing to pay higher } \\
\text { prices for Apple rather than the } \\
\text { other brands. }\end{array}$ & \multirow[t]{5}{*}{ Foroudi et al. (2018) } \\
\hline & & $\begin{array}{l}\text { I will not buy other brands if Apple } \\
\text { is available at the store. }\end{array}$ & \\
\hline & & $\begin{array}{l}\text { I prefer buying from the Apple } \\
\text { brand }\end{array}$ & \\
\hline & & $\begin{array}{l}\text { I consider myself is a loyal } \\
\text { customer of Apple }\end{array}$ & \\
\hline & & $\begin{array}{l}\text { Apple will be my first choice of } \\
\text { technology items }\end{array}$ & \\
\hline & & $\begin{array}{l}\text { When someone searches my advice } \\
\text { I will introduce Apple to them. }\end{array}$ & Nam et al. (2011) \\
\hline & & $\begin{array}{l}\text { Apple will be my first choice in the } \\
\text { future }\end{array}$ & Leckie et al. (2017) \\
\hline
\end{tabular}

